Wortley, R., \& Townsley, M. (2016). Environmental criminology and crime analysis: Situating the theory, analytic approach and application. In R. Wortley \& M.

Townsley, M. (eds). Environmental Criminology and Crime Analysis ( $\left.2^{\text {nd }} \mathrm{ed}\right)$.

London: Routledge. ISBN 9781138891135 


\title{
ENVIRONMENTAL CRIMINOLOGY AND CRIME ANALYSIS: SITUATING THE THEORY, ANALYTIC APPROACH AND APPLICATION
}

\author{
Richard Wortley and Michael Townsley
}

\section{Introduction}

Environmental criminology is a family of theories that share a common interest in criminal events and the immediate circumstances in which they occur. According to Brantingham and Brantingham (1991, p. 2), 'environmental criminology argues that criminal events must be understood as confluences of offenders, victims or criminal targets, and laws in specific settings at particular times and places'. Environmental criminologists look for crime patterns and seek to explain them in terms of environmental influences. From these explanations they derive rules that enable predictions to be made about emerging crime problems, and that ultimately inform the development of strategies that might be employed to prevent crime.

Crime analysis is an investigative tool, defined as 'the set of systematic, analytical processes that provide timely, pertinent information about crime patterns and crimetrend correlations' (Emig et al, 1980). It uses crime data and police reports to study crime problems, including the characteristics of crime scenes, offenders and victims. Crime patterns are analysed in terms of their socio-demographic, temporal and spatial qualities, and may be represented visually using graphs, tables and maps. Using these findings, crime analysts provide tactical advice to police on criminal investigations, deployment of resources, planning, evaluation, and crime prevention. 
Where the job of the crime analyst is to describe and interpret crime patterns, the job of the environmental criminologist is to develop a theoretical understanding of them. These two tasks are highly interdependent and each informs the other. On the one hand, crime analysts provide the facts that are the focus of environmental criminology and which are needed by environmental criminologists to develop and test their theories. On the other hand, environmental criminology is increasingly used by crime analysts to guide them in the questions they ask of crime data and in the interpretations that they place on their findings. Together, environmental criminology and crime analysis (ECCA) comprises efforts to use knowledge about the relationship between crime and the immediate environment in order to do something about crime problems.

The concerns of ECCA contrast sharply with those of most other criminological approaches. Traditional criminological theories are primarily concerned with criminality. They seek to explain how biological factors, developmental experiences and/or social forces create the criminal offender. In this, they take an historical perspective, focussing on the distant causes of crime. The occurrence of crime is understood largely as an expression of the offender's acquired deviance, which may be a function of events that occurred many years beforehand. Once the criminal has been created, crime is seen as more or less inevitable: the exact location and timing of the criminal act is of little interest. The prevention of crime is viewed in terms of changing offenders' fundamental criminality through enriching their childhoods, removing social disadvantage, and - once they have offended - providing them with 
rehabilitation programmes.

ECCA takes a very different view. Here crime is the object of interest. The offender is just one element of a criminal event, and how offenders come to be the way they are is of little immediate relevance. Instead, the focus is on the current dynamics of crime - where did it happen, when did it happen, who was involved, what did they do, why did they do it, and how did they go about it? The aim of the ECCA is to prevent crime, not to cure offenders or reform society.

ECCA is based on three contingent propositions.

(1) Criminal behaviour is significantly influenced by the nature of the immediate environment in which it occurs. The environmental perspective depends upon the principle that all behaviour results from a person-situation interaction. The immediate environment is not just a passive backdrop for criminal behaviour but rather it plays a fundamental role in initiating the crime and shaping its course. Thus, crime events result not only from criminogenic individuals; they are equally caused by criminogenic elements of the crime scene.

Environmental criminology explains how immediate environments affect behaviour and why some environments are criminogenic.

(2) The distribution of crime in time and space is non-random. Because criminal behaviour is dependent upon situational factors, crime is patterned according to the location of criminogenic environments. Crime will be concentrated around crime opportunities and other environmental features that facilitate 
criminal activity. Crime rates vary from suburb to suburb and from street to street, and may peak at different times of the day, different days of the week, and different weeks of the year. The purpose of crime analysis is to identify and describe these crime patterns.

(3) Understanding the role of criminogenic environments and being aware of the way that crime is patterned are powerful weapons in the investigation, control and prevention of crime. This knowledge allows police, crime prevention practitioner and other interested groups to concentrate resources on particular crime problems in particular locations. Changing the criminogenic aspects of targeted environment can reduce the incidence of crime in that location. Environmental criminology and crime analysis combine to provide practical solutions to crime problems.

Across these three domains of theory, analysis and practice, ECCA is multidisciplinary in its foundations, empirical in its methods, and utilitarian in its mission. ECCA draws on the ideas and expertise of sociologists, psychologists, geographers, architects, town planners, industrial designers, computer scientists, demographers, political scientists and economists. It embraces measurement and the scientific method, and it is committed to building theories and providing advice that are based on rigorous analysis of the available data. Finally, environmental criminologists and crime analysts actively engage with law enforcement personnel and crime prevention practitioners to help reduce crime.

The purpose of the current volume is to bring together the key components of ECCA 
and, in doing so, to comprehensively map the field. Despite the apparently unifying definitions and attributes outlined above, the environmental perspective encompasses a varied collection of approaches. Beneath a shared concern with crime patterns and the environment are differing levels of analyses, methods of enquiry and explanatory models. In this chapter, we unpack the historical roots of ECCA and outline the key concepts that have emerged within the field. In the process, we demonstrate our logic for showcasing the work of leading theorists and researchers in ECCA. We begin with an analysis of the early influences on the environmental perspective on crime. We then describe the chronology of work that has shaped our contemporary understanding of ECCA. We conclude with a synopsis of the chapters of this edited volume, emphasising the links between them in order to present ECCA as a unified field of study.

\section{Historical Roots of the Environmental Perspective}

The contemporary array of approaches in ECCA reflects the diverse roots from which the perspective has sprung. The influences have come down through different disciplines that in turn have viewed the relationship between crime and the environment through an analytic lens set at different levels of magnification. Brantingham and Brantingham (1991) identified three levels of analysis in the environmental perspective - macro, meso and micro - and it is useful to trace the foundations of the field in terms of these categories. 


\section{Macro-analytic roots}

Macro analysis 'involves studies of distribution of crime between countries, between states or provinces or cities within a particular country, or between the counties or cities within a state' (Brantingham and Brantingham, 1991, p. 21). Analysis at this highly-aggregated level constituted the earliest way of conceptualising environmental influences on crime, and indeed, studies of this sort represented some of the first 'scientific' criminological research.

Pioneering this line of research in the late 1820s, Andre-Michel Guerry and Adolphe Quetelet independently conducted detailed analyses of French crime statistics (see Beirne, 1993). From this research came the first recognisable examples of crime maps, depicting crime rates for the provinces of France. The maps were shaded to reflect various socio-demographic features such as poverty and education levels. Guerry and Quetelet both found that crime was not evenly distributed across the country, and further, that the distribution varied according to the crime in question. Contrary to expectations, violent crime was highest in poorer rural areas while property crime was highest in wealthy, industrialised areas. From this they reasoned that poverty did not cause property crime, but rather, opportunity did. Wealthy provinces had more to steal. Their observation about the role of opportunity has remained a central principle of environmental criminology through to the modern era. Likewise, the use of maps to represent crime trends has become the standard technique of crime analysis. 
Similar studies in other countries soon followed, as did comparisons between countries (see Brantingham and Brantingham, 1991). For example, research in England in the late nineteenth century found wide differences in crime rates across counties, again with higher rates reported for urban and industrialised areas than for rural areas. Macro-level analysis of crime trends continued into the twentieth century. In the US, significant and stable differences in crime rates and patterns were found among cities and states. However, there are limits to what such aggregated data can show. Inevitably, as we will see in the following sections, there was trend towards analysis at higher levels of resolution.

\section{Meso-analytic roots}

Meso analysis 'involves the study of crime within the subareas of a city or metropolis' (Brantingham and Brantingham, 1991, p. 21). These areas represent intermediate levels of spatial aggregation, and may range from suburbs and police districts down to individual streets and addresses. We present two early contributions to the meso-level analysis of crime and the environment, that of the Chicago School and the writings of Jane Jacobs.

The Chicago School pioneered the human ecology movement in sociology and criminology. Ecology is a branch of biology that examines the intricate balance achieved by plant and animal life within their natural habitat. The basic premise of ecology - that individual organisms must be studied as part of a complicated whole was adopted by a group of sociologists at Chicago University and applied to the study 
of human behaviour. Members of this group included Robert Park, Ernest Burgess, Clifford Shaw and Henry McKay. In particular, this group is noted for its research on migration trends within urban communities and the effects on criminal activity and other forms of social disorder. In this research, the city was conceptualised as superorganism comprising a collection of sub-communities based around ethnic background, socio-economic class, occupation, and so on. Members within these subcommunities were bound together by symbiotic relationships, and the subcommunities in turn were in symbiotic relation with one another (Park, 1952). However, ecological equilibrium is subject to change. In the natural world, a new plant may invade and dominate an area until it becomes the successor species. A similar pattern occurs in cities. Burgess (1928) proposed that the city could be divided into five concentric rings or zones. At the centre, Zone I, was the business district; around this was Zone II, where the poorest citizens lived in old, run-down houses; then came Zone III, where workers lived in modest houses; there was another step up the social ladder in Zone IV; and finally, Zone V comprised satellite suburbs from where relatively affluent commuters travelled. With population growth, there is a natural process of invasion, domination and succession as citizens migrate from inner to outer zones.

During the 1930s Shaw and McKay built on these observations to investigate the relationship between neighbourhoods and delinquency (see Shaw and McKay, 1969). They found that delinquency was greatest in Zone II. The neighbourhoods in Zone II contain the poorest citizen, have the least effective social and economic support systems, and offer the most criminal opportunities. In addition, these neighbourhoods 
are subject to two kinds of invasion. First, because they are adjacent to the industrial and commercial centre, they are put under pressure as the central area expands and fewer buildings are available to live in. Second, because Zone II has the cheapest housing, new immigrants are drawn to it. The influx of immigrants, many with adjustment problems associated with their immigrant status, increases the social disorganisation of the neighbourhood through cultural transmission. However, as residents of Zone II become more financially secure and make their gradual journey to outer zones, they do not take their delinquency with them. That is, the lesson for the environmental perspective is that the social problems exhibited in Zone II are features of the neighbourhood conditions rather than inherent features of the individuals who reside there.

The second significant influence on the environmental perspective at the meso level was the work of Jane Jacobs. Jacobs was a journalist and activist, not an academic. Indeed, she did not have a college degree, nor any formal training in the topics on which she wrote. Nevertheless she set out a number of important ideas that have become absorbed into environmental criminology, while even those ideas that challenge current assumptions in environmental criminology have been the catalyst for debate and research. Like members of the Chicago School, she was interested in cityscapes and the built environment, but at a more local, street level. Moreover, her work contained clear prescriptions for reducing crime. She took particular aim at the urban renewal projects that became endemic in post-war America and elsewhere. In 1961 she published The Death and Life of Great American Cities in which she argued that many of the orthodox indices of poor city planning - the intermingling of 
industrial, commercial and residential areas; the division of neighbourhoods into small city blocks divided by a criss-cross of streets; the presence of aging buildings; and the reliance on high density living with the corresponding absence of open, green spaces - did not actually predict social disorganisation. Using the North End district of Boston as an example, she demonstrated that an area regarded by many as a slum could in fact be well-maintained, vibrant, and relatively crime-free. Despite breaking the accepted rules of good urban design - or more accurately, because these rules were broken - the environment of North End created opportunities for residents to interact and to develop mutual support systems. Based on these observations, Jacobs proposed a radical rethink of urban design principles.

Crime occurs, Jacobs argued, when residents feel isolated and anonymous, and believe that they have no stake in their neighbourhood. What mattered, therefore, were planning policies that helped bring people together and to foster a sense of community. Jacobs set out four conditions of urban design to put these principles into practice. First, the district should cater to a multitude of purposes. The inclusion of commercial, industrial and recreational activities in residential areas means that streets and parks are in constant use and residents can interact with each other at all times of the day. Second, districts should be divided into small blocks with frequent corners and inter-connecting streets that permit residents to readily access all areas. Such a configuration creates permeability, unifying the district and ensuring that there are no deserted backstreets and other dead zones. Third, there should be a mixture of new and older buildings to ensure a diversity of enterprises that the district a can support. While banks, chain stores and the like can afford the infrastructure costs of 
new buildings, restaurants, bookstores, antique shops and other establishments that are essential to the cultural life of the district are typically found in older buildings. Finally, population density needed to be sufficiently concentrated to support diversity and to facilitate the interaction among residents. The problems often associated with high-density living, she argued, have often more to do with the nature of the featureless tower blocks that residents are forced to inhabit rather than population density per se. Together, these planning principles were designed to get people onto the streets. This not only helped build social networks for their own sake, but it also encouraged residents to notice outsiders and to provide informal surveillance of the neighbourhood. This, she referred to as having 'eyes on the street'. An important consequence, therefore, was increased community safety. In advancing these proposals, Jacobs foreshadowed the explicit crime prevention mission of the environmental perspective.

\section{Micro-analytic roots}

Micro-analysis examines specific crime sites, focussing on 'building type and its placement, landscaping and lighting, interior form, and security hardware' (Brantingham and Brantignham, 1991, pp. 21-22). In comparison to ecological approaches, micro-level analysis reflects an increasingly reductionist philosophy where the whole is broken down into its smaller constituent parts. At this level, the focus is on the effects that specific elements of the immediate environment have on specific decisions and behaviours of individuals. Crucial in the development of this line of analysis were debates in psychology about the locus of the causes of 
behaviour.

Psychology as a discipline has been traditionally concerned with the investigation of individual differences. A great deal of psychological theory and research is devoted to the study of internal constructs, or traits - personality, attitudes, beliefs, and so on that are assumed to drive behaviour and to differentiate on person from the next. In classic trait theory, the psychological makeup of each individual is seen to comprise various dimensions, and on each dimension an individual can be located somewhere along a continuum. For example, everybody is presumed to fall somewhere along an extraversion/introversion dimension. Once acquired, a person's psychological attributes are viewed as being more-or less fixed. Everybody can be described in terms of their characteristic personality profile and on this basis their behaviour in new situations can be reliably predicted. Someone described as extraverted will behave in an extraverted fashion in most circumstances, and can be readily distinguished from a person who is described as introverted. It is the person's psychological makeup that largely determines how they behave.

This theoretical focus on dispositions parallels the way human beings intuitively account for events. In our everyday experience, we have a natural tendency to see individuals as being fully in charge of their actions. This is particularly so where the outcomes are negative. Psychologists call this cognitive bias the fundamental attribution error (Jones, 1979; Ross, 1977). We typically overestimate the role of other peoples' personal characteristics when assessing their responsibility for undesirable behaviour, while at the same time we discount of the role of immediate 
environmental factors. Perhaps not surprisingly, this does not apply when we assess our own bad behaviour - we are only too happy to cite the role of extenuating environmental circumstances in our own case. We are angry because we didn't sleep well; he/she is angry because he/she is an aggressive person. This ingrained faith that behaviour is caused largely by an individual's psychological disposition can make it difficult to sell the environmental perspective on crime.

However, though dominant, the dispositional model has never been universal in psychology, and there is simultaneously a long history of theory and research that has been interested in the way that behaviour is influenced by the immediate environment. This alternative tradition was cogently articulated by Walter Mischel in 1968. Mischel brought to prominence the so-called cross-situational consistency debate, which revolves around the extent to which people possess underlying traits that remain stable from one situation to the next. Drawing particularly on the conditioning models in learning theory, Mischel advocated a position of behavioural specificity. According to Mischel, the way an individual behaves can vary dramatically from one situation to the next, depending upon the nature of the immediate environmental influences. If we think for a moment about our own behaviour we recognise that we behave differently in different contexts - for example, we may act one way with our colleagues and another with our family.

Applied to criminal behaviour, the principle of behavioural specificity has important implications. In the first place, it suggests that the performance of criminal behaviour is not restricted to a small, definable group of offenders with criminal dispositions - 
given the right circumstances, most people are capable of illegal conduct. Rape, for example, is a frequent occurrence in war zones and is often carried out by soldiers who in other circumstances would never have contemplated such behaviour. But furthermore, even chronic, predatory offenders do not commit crime all of the time nor indiscriminately - in fact they offend relatively infrequently and only under certain favourable conditions. Knowledge of the precise circumstances in which crime occurs is crucial for a complete understanding of criminal conduct and traditional theories of criminology that are devoted to explaining the development of criminality as a fixed attribute are missing a key ingredient. Micro-level analysis has become particularly influential in the development of crime prevention strategies within the environmental perspective.

\section{Contemporary Environmental Approaches}

By general agreement, the birth of the modern environmental criminology perspective in criminology can be dated quite precisely to 1971. In that year C. Ray Jeffery published Crime Prevention Through Environmental Design, in which he examined the role that immediate environments play in crime and suggested a range of strategies for reducing crime by modifying immediate environments. He also coined the term environmental criminology. Within fifteen years of the publication of Jeffery's book, most of the seminal approaches of ECCA had appeared, with later developments largely building on these foundations. 
The chronology of these seminal publications is shown in Table 1.1. However tracing the development of ECCA in terms of a single progression of ideas is not a very satisfactory analytic strategy. ECCA comprises a number of inter-related approaches that have developed more-or-less in tandem with one another. Our aim in this section is to highlight the chronology of intellectual thought within each approach, and to indicate the key areas of cross-fertilisation among the approaches. We examine the development of ECCA in terms of four broad themes set out in these foundational writings - designing out crime, situational crime prevention, understanding and analysing crime patterns, and policing for crime reduction. Because of the overlaps among approaches, we acknowledge others might carve out the field in different ways.

\section{Table 1 about here}

\section{Designing out Crime}

We start with designing out crime since it was Jeffery's (1971) Crime Prevention through Environmental Design (usually shortened to CPTED) that heralded what we can now recognise as the golden age of ECCA. Jeffery set out a wide-ranging vision of crime control covering the role of architecture, town planning, legal sanctions, social systems, and even exposure to lead. Jeffery was heavily influenced by the operant conditioning models of Skinner (1953), which had provided much of the theoretical and empirical support for the situational side of the cross-situational consistency debate outlined earlier in this chapter. Skinner argued that behaviour was 
controlled by its consequences, and Jeffery thought the key to crime control was through the design of physical environments and the implementation of social policies that systematically decreased the rewards for criminal behaviour and increased the risks. He also recognised that criminal behaviour cannot occur without opportunity, which he saw as a necessary but not sufficient condition for crime. Jeffery's position was perhaps the most radical in the environmental perspective, based on a biosocial model of offenders and amounting to situational determinism. 'There are no criminals' he declared, 'only environmental circumstances that result in criminal behaviour. Given the proper environmental structure, anyone will be a criminal or a non-criminal' (Jeffery, 1977, p. 177).

Jeffery's CPTED was essentially a theoretical treatise setting out the principles for designing out crime but providing little in the way of prescriptive solutions. The deterministic and biologically based arguments made by Jeffery found little appeal among scholars at the time, and the ideas expressed in the book had limited impact. Moreover, the book was quickly overshadowed by a narrower version of environmental design put forward by Oscar Newman (1972) in his book Defensible Space: Crime Prevention Through Urban Design published just one year later. Newman, an architect, focussed exclusively on the design of the built environment. His concept of defensible space extended Jacob's ideas about the need for residents to take responsibility for crime in their immediate neighbourhoods (although in other ways he departed from her prescriptions, especially with respect to her encouragement of neighbourhood permeability). Defensible space can be created in a number of ways. First, Newman proposed strategies for increasing in residents their sense of 
ownership over private and semi-public space by more clearly defining territorial boundaries. This might be achieved through the erection of real and symbolic markers such as fences and gates, or through displaying conspicuous signs that an area is occupied and cared for. Second, he suggested ways of increasing opportunities for natural surveillance so that criminal activity might be better observed. This might be achieved through the placement of windows, the routing of pedestrian traffic, the elimination of blind-spots and so forth. Newman had little to say about the nature of offenders and thus he avoided the theoretical controversies surrounding Jeffery's book. Defensible space was based on a simple, common sense deterrence principle: the primary focus was to change the behaviour of residents who then, through their increased vigilance, deterred potential intruders.

Jeffery's term CTPED has stuck and is now the generic name for the field, but it has been Newman's narrower architectural approach that has proved the more popular and enduring. Newman was able convert his theoretical musings about territoriality and surveillance into practical recommendations that could be incorporated into building standards. CPTED has gone through some modifications over the years and remains widely used today, especially among architects and urban planners (see Armitage, chapter 12, this volume). As we shall see, the influence of CPTED can also been seen in each of the other environmental approaches described below.

While CPTED remains focussed on the build environment, the idea of designing out crime expanded to other areas, notably the design of products. Illustrating the cross fertilisation across approaches, the impetus for developments in designing products 
against crime in fact owes more to the situational approach of Ron Clarke (described in the next section) than it does the Jeffery or Newman. An early insight of Clarke's was that some products were inherently criminogenic because they were attractive and easy to steal. Based on this observation, Paul Ekblom (then part of Clarke's research team at the British Home Office) wrote an article speculating on the design of the crime-free car (Ekblom, 1979), while Clarke himself published the influential Hot Products: Understanding, Anticipating and Reducing Demand for Stolen Goods in 1999. There is now an active research program in designing products against crime involving the collaboration between environmental criminologists and designers (Ekblom, chapter 14, this volume). Design against crime is sometimes used as a generic label to cover CPTED, product design and other design-related crime prevention initiatives (e.g., design of systems, procedures, services, and communications).

\section{Situational Crime Prevention}

The next major contribution to ECCA came in the mid-1970s with Ron Clarke's development of situational crime prevention (SCP) (see Clarke, chapter 13, this volume). Arguably SCP can be considered a version of design against crime, but it has a number of distinctive features and has taken on a life of its own, warranting its treatment as a separate approach. SCP represents the micro-level extreme of the environmental perspective. Clarke argued that the key to crime prevention was to focus on very specific categories of crime, and to understand their precise situational dynamics. His approach incorporated aspects of Newman's defensible space, but 
philosophically it owes a greater debt to the psychological theories examined by Jeffery. Like Jeffery, Clarke saw reduction of opportunity and the manipulation of the costs and benefits of crime as the bases for prevention. However, Clarke offered what Jeffery did not, and that was a comprehensive set of concrete techniques for operationalising his crime prevention principles. SCP also involves a problem solving method that is applied to existing (rather than anticipated) crime problems in order to devise effective ways to redesign criminogenic environments.

The publication of Crime as Opportunity (Mayhew, Clarke, Sturman and Hough, 1976) marked the first manifesto for SCP (although the term SCP wasn't used until Clarke, 1980), but earlier writings by Clarke on the role of situations in crime predate the books of Jeffrey and Newman. In 1967 he published a research paper on absconding from a residential school for juvenile delinquents (Clarke, 1967). Unable to find consistent personal variables that predicted absconding, he found instead that absconding rates varied according to a number of institutional factors. The best way to prevent absconding was not to identify potential absconders, but rather to change the way that institutions were built and run. While head of the British Home Office Research Unit during the 1970s, Clarke began developing this idea into a comprehensive model of SCP and set about putting the prevention principles into practice.

The psychological bases of situational prevention were made more explicit with the development of the rational choice perspective (Clarke and Cornish, 1985; Cornish and Clarke, 1986; Cornish and Clarke, chapter 2 this volume), which was formulated 
to underpin the model. In the rational choice perspective, offenders are portrayed as active decision makers who use environmental data to make purposive decisions about engaging in a particular crime. These decisions can be considered rational inasmuch as the offender seeks to benefit in some way from the contemplated behaviour. Crime will occur when the perceived benefits outweigh the perceived costs. The practical implication of rational choice perspective, delivered though situational crime prevention, is that crime can be reduced by reducing criminal opportunities by creating the circumstances that make committing crime on that occasion an unattractive option from the perspective of the decision-maker.

One development in the rational choice perspective - introduced in a prototypical form in Clarke and Cornish's original 1985 paper and more fully fleshed out in a paper by Cornish in 1994 - was the crime script. The crime script represents a recognition that the crime event does not occur as a single point in time and space, but rather, it may take days or even weeks to accomplish and activity can occur at multiple locations. A burglary, for example, may start with the offender researching likely targets and assembling the necessary tools perhaps days before the event, and end with the offender trying to sell the stolen goods days after the event. Between the start and end there may be dozens of individual steps (driving to the target, breaking in, deciding what to steal, etc). Thus there is not just one decision point at which rational choices are made but many, and each decision point offers an opportunity for intervention (see Leclerc, chapter 6, this volume).

Clarke developed a table of SCP techniques as a guide to practitioners. Over the 
years, the table has evolved and expanded to account for additional theoretical insights on offender decision-making. His original table appeared in 1992 (Clarke, 1992) and involved three prevention strategies - reducing of rewards, increasing risks and increasing effort - yielding 12 specific prevention techniques. In 1997, in collaboration with Ross Homel, he added a fourth column that examined techniques for removing excuses for crime, bringing the total number of techniques to 16 (Clarke and Homel, 1997). The basis for this strategy was the observation that, aided by environmental conditions, offenders may seek to reduce personal inhibitions by minimizing the perceived criminality of their behaviour. An additional column, reducing provocations, was added in 2003, and the total number of techniques increased to 25 (Cornish and Clarke, 2003; see Clarke, chapter 13, this volume). This revision was in response to Richard Wortley, who argued that situations can actively precipitate criminal behaviour (Wortley, 2001, 2002). Wortley drew on a range of psychological theories that supported the principle of behavioural specificity. According to his argument, offenders do not necessarily enter the crime scene motivated to exploit criminal opportunities. Situational factors, such as peer pressure and environmental stress, can induce individuals to commit crimes they might not have otherwise considered (see Wortley, chapter 3, this volume).

\section{Understanding and Analysing Crime Patterns}

Jeffery, Newman, Clarke and Cornish, and those who followed them, were interested in why certain environments facilitate crime and what can be done to redress their criminogenic properties. Another strand of research, originating in the demographic 
crime maps of Guerry and Quetelet and the ecological analysis of intra-city crime patterns described by the Chicago School, is concerned with the way that these criminogenic environments, and therefore also crime, are distributed in time and space.

Around the time that Clarke was taking the environmental perspective to more finegrained levels, Cohen and Felson (1979) were examining crime patterns and trends in terms of broad social forces. Applying what they described as a routine activities approach (RAA), Cohen and Felson set out to explain the apparent paradox that crime rates after World War II rose substantially at the same time that economic conditions improved. According to traditional criminological theories that associated crime with poverty, crime rates might have been expected to fall during this period. Paying explicit homage to Guerry, Quetelet and the Chicago School, they argued that higher crime rates could be explained by the changes in the routine activities that accompanied economic prosperity. Crime was caused, they said, by 'the convergence in space and time of the three minimal elements of direct-contact predatory violations: (1) motivated offenders, (2) suitable targets, and (3) the absence of capable guardians against a violation' (p. 589). Improved economic conditions often had the incidental effect of bringing these three elements into alignment. For example, with the increased participation of women in the workforce, there was an accompanying increase in the number of houses left unattended during the day. At the same time, growing affluence and technological advances meant that there were more valuable personal possessions available to steal. These factors helped explain why rates of daytime residential burglaries doubled between 1960 and 1975, while the rates for 
commercial burglaries almost halved.

While RAA was originally pitched at the macro-analytic level, it has been very influential in ECCA generally. Subsequent refinements by Felson (1994; 1998; chapter 4 this volume) explored the meso- and micro-level implications of the approach, and the compatibility of RAA with rational choice and situational crime prevention (Clarke and Felson, 1993). It was realised that the three necessary elements for crime - an offender, a target and an absent guardian - provided a framework for analysing the dynamics of individual crime events and for determining points of intervention for crime prevention. For example, some crimes occur because of the easy accessibility of vulnerable targets and so intervention requires targethardening strategies; other crimes are the result of poor management of facilities and so require interventions that strengthen guardianship. The familiar crime-triangle (offender, locations, target) used in operational policing is based on the routine activities approach (Clarke and Eck, 2003. See also Scott, Eck, Knutsson and Goldstein, chapter 11, this volume).

Most people know RAA for the three necessary elements of crime, but the real insight offered by Cohen and Felson is that the convergence of these three elements is not haphazard but is explicable in terms of the natural rhythms of everyday life. RAA suggests that crime will concentrate where the routine movements of victims and offenders overlap and that the source of these movements can be legitimate activities unrelated to crime. Still, RAA says little about how these elements converge in time and space. Explaining this convergence is the subject of Paul and Patricia 
Brantingham's crime pattern theory, introduced in the chapter Notes on the Geometry of Crime in their edited volume Environmental Criminology in 1981, a book that also marks the first exposition of 'environmental criminology' as a distinct field of study.

Crime pattern theory attempts to account for the non-uniformity and non-randomness that characterises the criminal event in the urban environment (Brantingham and Brantingham, 1984; 1993; Brantingham, Brantingham and Andresen, chapter 5, this volume). Central to this approach is the principle that the everyday movements of offenders and non-offenders alike are dominated by the need to travel to and from work, school and certain community or recreational locations. In crime pattern theory, these key locations that an individual frequents are referred to as nodes, and the regular routes that connect them are referred to as paths. Individuals become particularly familiar with areas around nodes and pathways that they visit frequently as a consequence of their daily routines. These areas are referred to as an individual's "awareness spaces". Crime is argued to occur in predictable locations defined by the intersection of an offender's awareness space and crime opportunities. Offenders prefer to commit crime within their awareness spaces since it is in these areas that they are likely to possess superior knowledge about available crime targets and possible risks. At the same time, some nodes - shopping centres, sports stadiums, transport hubs and the like - where both potential offenders and victims congregate, offer abundant crime opportunities, creating crime concentrations, or hotspots.

The work of the Brantinghams provided much of the theoretical bases for understanding and predicting crime patterns. Advances in empirically analysing crime 
patterns were in turn aided by the widespread availability by the 1990s of geographic information system (GIS) software for personal computers. Mapping technology allowed the spatial and temporal distribution of crime to be readily modelled, and in particular, hotspots to be easily identified. The publication by Sherman, Gartin and Bueger (1989) of an analysis of hotspots for predatory crime heralded a new era of applied mapping research. Hotspots became the obvious priority for policing resources and crime prevention efforts (see Johnson, chapter 10, this volume).

In addition to crime hotspots, a number of specific crime patterns have attracted research attention because of the implications they have for crime prevention and detection. Consistent with the predictions of crime pattern theory, journey to crime research reveals that offenders tend to commit their crimes close to home and along familiar pathways, following a characteristic distance decay pattern (Rengert and Wasilchick, 2000; see Townsley, chapter 7, this volume). Applying a technique called geographic profiling, this finding has been used to model the mobility patterns of individual serial offenders in order to make estimates about where the offender is likely to live, work and move (Rossmo, 2000; see Rossmo and Rombouts, chapter 8, this volume). Finally, the phenomenon of repeat victimisation, in which certain places or people are found to be victimised on multiple occasions, identifies vulnerable targets for the priority allocation of crime prevention resources (Farrell and Pease, 1993; see Farrell and Pease, chapter 9, this volume).

\section{Policing for crime prevention}


All of the approaches discussed so far have, to varying degrees, implications for policing. The identification of crime patterns such as hotspots is perhaps the most obviously applicable, but depending upon the policing commitment to crime prevention, CPTED and SCP also provide valuable insights. In this section we examine two approaches that have been formulated specifically with policing in mind.

The first is Herman Goldstein's (1979) problem oriented policing (POP). In contrast to other approaches discussed so far, POP does not advance any particular theory of crime or describe any crime patterns. It is concerned with the equipping police with the necessary methods and tools to implement environmental interventions rather than specifying what the content of those interventions might be. POP emphasises the need to move away from a reactive to a proactive model of policing. It provides a general problem-solving framework for police to intervene to prevent crime problems within their jurisdiction before those problems develop or get out of control. But, insisted Goldstein (1990), it is also more than this: 'In its broadest context, it is a whole new way of thinking about policing that has implications for every aspect of police organization, its personnel, and its operations' (p. 3). POP seeks to transform fundamentally the way that policing is conceptualised.

Goldstein's colleagues, John Eck and Bill Spelman operationalised the problemoriented policing approach by setting out an action model for tackling crime problems. They summarized the steps in this model using the acronym SARA, standing for scanning, analysis, response and assessment (Scott, Eck, Knutsson and Goldstein, chapter 11, this volume). The first step is to scan for recurring crime 
problems, grouping similar incidents into clusters. Information about the crime problem must then be collected and analysed, and the underlying causes identified. Based on this intelligence, a tailor-made response is formulated. Finally, the effectiveness of the response is assessed, and if necessary (i.e., the response is ineffective), the process starts again. Within this framework, the actual strategies available to police are not prescribed. Rather the officer is encouraged to search for novel alternatives to traditional policing responses. After careful analysis of the problem, the responses are only limited by the officer's enthusiasm and creativity. In this regard, POP and SCP make good bedfellows. SCP provides a theoretical framework and pool of possible prevention techniques that is lacking from POP. In turn, SARA provides a useful action research model that SPC practitioners might use to conduct a situational analysis of criminogenic locations and to brainstorm possible situational interventions.

The second distinctly policing model is offered in James Q Wilson and George Kelling (1982) Broken Windows; The Police and Neighborhood Safety. The Broken Windows article stemmed from the research of Kelling and his colleagues on the Fear Reduction Experiments in Newark and Houston, funded by the National Institute of Justice in the US Department of Justice. The foot patrol experiment in Newark was particularly influential in creating the foundations of the Broken Windows metaphor. With echoes of Jacobs and Newman, Wilson and Kelling addressed the role of neighbourhood decay in crime and the implications for policing. They argued that lack of attention to small signs of neglect and petty crime can lead to more serious crime problems. Fixing broken windows is a metaphor for addressing these 
criminogenic incivilities. In contrast to POP, the broken windows approach is built on a central idea about crime causation and also contains explicit crime prevention instructions. Theoretically, Wilson and Kelling drew on CPTED and psychological research showing the influence of situations on behaviour to explain the effects of broken windows on offending. The approach was famously institutionalized as an operational police tactic when it was espoused as the justification for the policing strategies employed by police chiefs such as William Bratton and Howard Safir under the mayor-ship of Rudolph Giuliani in New York City during the 1990s (see Wagers, Sousa and Kelling, chapter 15, this volume). Most controversially, the broken windows approach was operationalised as the vigorous enforcement of laws against disorderly behaviour and other minor offences. Some commentators credit the broken windows approach as being instrumental in contributing to New York City's significant drop in crime rate.

\section{Conclusion and Organisation of this Book}

From disparate beginnings, ECCA has emerged to become arguably the fastest growing approach in criminology. Once regarded by many criminologists as esoteric and largely peripheral to the main game, the approach has increasing acceptance and influence. The relatively small and scattered group of original researchers in the field has been joined by a new wave of academics and practitioners from around the world, making the approach truly international. Perhaps more than most criminological approaches ECCA is well placed to respond to the increasingly global, organised and technologically-assisted nature of crime in the $21^{\text {st }}$ century. The problems to which 
ECCA principles have been applied in recent years include organised crime (Bullock, Clarke and Tilley, 2010), cyber crime (Holt and Bossler, 2015; McNally and Newman, 2007; Newman and Clarke, 2003), Internet child exploitation (Wortley and Smallbone, 2006; 2012), human trafficking (Brayley, Cockbain and Laycock, 2011; Cockbain and Wortley, 2015; Savona, Giommoni and Mancuso, 2013), wildlife poaching (Lemieu, 2014, Moreto and Clarke, 2013), terrorism and insurgency (Braithwaite \& Johnson, 2012; Freilich and Newman, 2009; Newman and Clarke, 2006; Townsley, Johnson and Ratcliffe, 2008), and maritime piracy (Marchione \& Johnson, 2013, Townsley, Leclerc, and Tatham, 2015; Townsley and Oliveira, 2015).

Still, there are few books that draw together all the various strands of ECCA. In this volume, in addition to this introductory chapter, we present fourteen original chapters by leading ECCA theorists and practitioners, most of whom are identified with developing the original concept which they present. Our aim is provide a comprehensive overview of ECCA, showing the way that key ideas and approaches interconnect to form a coherent field of study. The order in which the contributions are arranged has an important role to play in this endeavour. As we have noted, a strictly chronological approach will not do. In the introduction to this chapter, we outlined three propositions on which ECCA is founded - that crime is best understood in terms of an interaction between the offender and the immediate environment; that crime is therefore patterned according to the distribution of criminogenic environments; and that these locations are the logical targets for interventions to prevent and control crime. Working sequentially through these three domains of theory, analysis and practice seems to us to be the most logical way of unfolding the 
ECCA story.

\section{Understanding the crime event}

In this section we present key the theoretical perspectives on the role that immediate environments play in crime in order to understand why crime events occur where and when they do. There are four chapters in this section and they address two different aspects of the crime-environment relationship. The first two chapters examine the psychology of the offender. We have previously argued that ECCA is concerned with crime not criminality. While this true, ECCA only makes sense if one begins with a psychological model of the offender that includes a fundamental role for the effects on behaviour of the immediate environment. With this model of the offender in place, the next two chapters consider explanations for how the offender's crimes are then patterned by the distribution of criminogenic environments in time and space. Rather than presenting contradictory views on the crime-environment nexus, these four models present explanations at different levels of analysis. Together they provide the theoretical bases for the environmental perspective that underpin the practices of crime analysis and crime prevention.

The first chapter (chapter 2) is the Rational Choice Perspective by Derek Cornish and Ron Clarke. We begin with RCP because it presents the basic template for the situational offender. Cornish and Clarke outline the historical development of RCP, noting its origins in learning theory and explaining the choice they made to shift to a 
model that included a role for cognitive processes. The underlying premise of RCP is that human beings are designed to act out of self-interest and hence they go through life making choices that they assume will maximise utility. Cornish and Clarke argue that offending behaviour is purposive - the offender sets out to commit crime in order to achieve some end - and that it is rational - that their behaviour represents an understandable strategy to achieve the desired end. Cornish and Clarke do not pretend that RCP provides a detailed account of offender psychology. Their intent is to describe the essential decision making mechanism that governs how the motivated offender interacts with the immediate environment. RCP need only be a 'good enough' theory to stimulate research and guide crime prevention practitioners. Their chapter concludes with a summary of some of the criticisms made of RCP, and their robust rebuttals of those criticisms.

In chapter 3 Richard Wortley furthers the analysis of offender psychology with Situational Precipitators of Crime. One criticism of RCP raised by Cornish and Clarke in the previous chapter is that made by Wortley. Unlike other attacks on RCP, Wortley's criticism is made from within ECCA. He does not contend that RCP is wrong but only that it is incomplete. In addition to situations providing information to the motivated offender about the likely consequences of criminal behaviour (the focus of RCP), he argues that situations can also play a role in creating or intensifying the motivations to commit crime. In this chapter Wortley sets out the case for including the concept of situational precipitators to augment the bared-boned model of the situation offender presented by Cornish and Clarke. Wortley points out that the idea that situations can initiate behaviour and cause people to perform acts they might not 
have otherwise carried out is included in numerous psychological perspectives.

Drawing across these perspectives he suggests four main ways situations can induce crime: they can prompt a criminal response, exert pressure on an individual to offend, weaken usual moral prohibitions to permit an individual to offend, and produce emotional arousal to provoke a criminal response. Wortley argues that the concept of precipitators can suggest new prevention techniques beyond opportunity reduction, especially for so-called expressive crimes.

With chapter 4 and Marcus Felson's Routine Activity Approach, we shift from examining the nature of the offender to the patterning of crime. In fact RAA says nothing about the offender beyond that he/she is 'motivated', and more recently, simply 'likely'. It is appropriate to begin the examination of crime patterns with RAA. RAA is at the same time the simplest and the most profound of crime theories $-\mathrm{a}$ classic example of Occam's Razor, which commands that 'we are to admit no more causes of natural things than such as are both true and sufficient to explain their appearances'. The three components of RAA - the offender, victim and absent guardian - provide the essential 'chemistry of crime'. The idea that these three elements come into contact via everyday movements of victims and offenders is at the heart of almost all subsequent explanations of offender mobility and the patterning of crime. In this chapter, Felson provides an overview of RAA and traces the history of its development, describing the explicit aim to keep the theory as simple as possible and to express the ideas in clear language. He goes on to outline the links between RAA and other approaches in ECCA, and the broadening of RAA in his subsequent publications Crime and Everyday Life and Crime and Nature. Finally, Felson 
summarises the lessons of RAA in fifteen points, statements that 'sum up the development of routine activity thinking over a third of a century, while reminding us that the fundamentals remain the same.'

Chapter 5, The Geometry of Crime and Crime Pattern Theory by Paul and Patricia Brantingham and Martin Andresen, completes this section. This chapter drills down from Felson's macro-level analysis to explain crime patterns at the neighbourhood and street level. The chapter presents two related theoretical perspectives. The geometry of crime seeks to explain the basic patterns of crime that are governed by the places that offenders live, work and play (their major nodes) and the journeys they take as they move between these locations (their pathways). Crime pattern theory then combines these ideas with RAA and RCP to form a comprehensive meta-theory of crime patterns. This chapter is structured by systematically working through ten rules that govern the patterning of crime. Rules are provided not just for individual offenders but also for networks of offenders. As each rule is examined the key features of the geometry of crime and crime pattern theory are progressively revealed. Together the geometry of crime and crime pattern theory provides a theoretical account of why crime clusters where and when it does, providing the basis for predicting and interpreting the crime patterns discussed in the next section.

\section{Analysing crime patterns}

In this section we look at commonly observed patterns of crime and some of the main 
analytic techniques used to examine them. While the previous section provides theoretical explanations for the patterning of crime, this section has an applied focus. It examines the empirical evidence for specific crime patterns and highlights the implications of these patterns for practitioners. In line with the crime triangle, the analyses covered in these chapters variously focus on the offender, the victim and the location of crime.

This section opens with chapter 6, Crime Scripts, by Benoit Leclerc. Crime scripting is an analytic technique for setting out the sequence of steps that comprise the crime event. We have selected this topic to open the analysis section because it sets out the basic principle that crime events consist of numerous sub-events each of which may require their own analyses. Crime scripts are an extension of the logic of RCP, and indeed, Cornish and Clarke introduced the concept in chapter 2 of this volume. The chapter begins with Leclerc tracing the origins of crime scripts from the concept of schema developed in cognitive psychology. Leclerc discuss some recent examples of the application of crime scripts and works through in detail the case of child sexual abuse to show how the technique can be used to assist the development of interventions. Recent developments in crime scripting include scripts that examine the offender-victim interchange to more fully capture the dynamic nature of the crime event.

Chapter 7, Offender Mobility by Michael Townsley, presents empirical evidence for some the crime patterns discussed in crime pattern theory. In particular, Townsley examines the so-called journey to crime literature. The research shows that the 
distance travelled by offenders to carry out their crimes is characteristically short, following a distance decay function. The distance decay pattern is a demonstration of the least effort principle - offenders will search for crime opportunities no further than they need to accomplish their goals. Townsley reviews the research examining variations in journey to crime in terms of offence variables - e.g., property versus violent crime - and offender variables - age, gender and ethnicity. He goes on to examine recent developments in analysing offender mobility. He discusses the need to examine the journeys made by individual offenders as opposed to aggregated data, pointing out that the variation in journey distances is less for individual offenders than the distribution of all crime trips would suggest. He also discusses the emerging research on discrete spatial choice analysis that seeks to incorporate a range of variables from additional sources (offender, target, etc.) in order to model more complex journey patterns.

The mobility of individual serial offenders is the focus of chapter 8, Geographic Profiling, by Kim Rossmo and Sacha Rombouts. Geographic profiling draws particularly on journey to crime research, using the principles set out in crime pattern theory about the movement of offenders within their awareness spaces around their primary nodes. By analysing multiple offending locations of a single offender, estimations can be made of the likely area where the offender resides, or other places (e.g. work location) that serve as an anchor point or base of operations. Rossmo and Rombouts begin the chapter by setting geographic profiling within its theoretical heritage in environmental criminology. They then describe the process by which a geographic profile is constructed. They point out that the profile needs to take account 
of the hunting style of the offender; for example some offenders search close to home (a "hunting/marauder" style) while others travel to other neighbourhoods (a "poaching/commuter" style). Rossmo and Rombouts discuss the broadening of geographic profiling from its original focus on violent crime to a wide range of offences types including burglary, fraudulent ATM withdrawals, rape, kidnapping, insurgency, and the purchase of bomb components. They conclude the chapter by working through a case study in which geographic profiling was used to investigate serial burglary involving 42 separate events. In this case, geographic profiling was successfully used to predict the likely location of the next burglary.

In chapter 9 by Ken Pease and Graham Farrell we turn our attention to victims with the examination of the phenomenon of Repeat Victimisation and its implications for crime prevention. Pease and Farrell report that up to $40 \%$ of crimes are examples of repeat victimisation, with offences for which repeats are prominent including burglary, robbery, shop theft, domestic violence, sexual victimisation, abuse of elders and children, racial attacks and bullying. Repeats may be perpetrated by the same offender repeating a successful strategy (e.g., a burglar returning to a previously burgled house because he/she is familiar with the layout) or by different offenders responding to a fundamental vulnerability of the target (e.g., a house that is repeatedly burgled because it has poor security). Pease and Farrell argue that targeting repeat victims is an especially efficient way of allocating policing and other resources to crime prevention. Repeat victimisation is the basis for prospective mapping techniques covered in the next chapter. 
Chapter10, Crime Mapping and Spatial Analysis, by Shane Johnson concludes this section. We have left this chapter to last because it sets out analytic techniques that can be applied to the patterns described in the earlier chapters. Crime mapping is a way of analysing and visually representing the clustering of crime in space, a technique commonly referred to as hot spot analysis. In this chapter, Johnson walks us through some of the technical aspects around creating crime maps. He highlights the need to represent crime rates (rather than just count) in order to fairly represent risk; he outlines the various types of maps, contrasting the advantages and disadvantages of grids and kernel density estimation; and he examines ways of determining how hot a hotspot is (i.e., its statistical significance) beyond applying the eyeball test. Johnson then examines how to address some of the inherent data limitations associated with mapping. He highlights the need to account for possible spill-over effects where what happens in one area of investigation can be affected by what has happened in another; he examines ways of accounting for the effects of unmeasured variables; and he examines the implications of factors that operate at different levels of spatial aggregation (e.g., household level versus street segment level). The chapter concludes with an examination of predicting future crime location via prospective mapping. As noted in the previous chapter, the logic of prospective mapping is built on the phenomenon of repeat victimisation, and more particularly, that of near repeats. Johnson shows how knowledge of repeat and near repeat victimisation patterns permits estimations to be made of short term future offending hot spots, and that directing police resources to these areas has promising implications for crime prevention.

\section{Preventing and controlling crime}


In this third and final section we examine the end-use application of environmental criminology and crime analysis. Understanding and analysing crime patterns can tell us where and when crime is likely to occur, but this understanding on its own is not necessarily sufficient to suggest effective intervention strategies. The perspectives covered in this section are concerned with what we actually do to address crime problems in those locations that are identified as criminogenic.

Chapter 11, by Michael Scott, John Eck, Johannes Knutsson and Herman Goldstein, is on Problem Oriented Policing. As we noted earlier, POP is not based on any particular environmental theory and nor does it propose any particular intervention strategies. We open with this section with this chapter because what it does provide is a generalizable problem-solving model - SARA - that can be applied to most crime prevention efforts and thus has implications for the chapters that follow. The chapter opens with a detailed breakdown of the defining features of POP. The chapter then turns to the application of POP. The SARA model and the crime triangle, adapted from the routine activities approach, are described. One extension of RAA in this version of the crime triangle is the distinction made between various types of guardians. Here the term guardian is used to describe those who protect targets or victims, while the term handler is used to describe those who might exercise control over offenders and manager is used to describe those who look after places or locations. The chapter concludes with an examination of the challenges in implementing POP, with the experience of POP in Nordic countries and the USA used to illustrate implementation issues. 
Crime Prevention Through Environmental Design, by Rachel Armitage, comes next as chapter 12. As we have discussed, historically CPTED was the first fully articulated environmental crime prevention model and we have placed it here because it sets out some basic principles that others have followed. Armitage begins by defining CPTED, describing its historical development, and outlining the links between CPTED and other environmental criminology perspectives. She then explains and evaluates the key elements of CPTED: defensible space and territoriality; limiting through movement; surveillance; physical security; and management and maintenance. In each case she describes what each element means, how it is operationalized, and the empirical evidence for its effectiveness. She then discusses the experience of CPTED in three countries - England/Wales, Australia and The Netherlands. She concludes with critical examination and evaluation of the criticisms and limitations of CPTED.

Chapter 13 is Ron Clarke's Situational Crime Prevention. Clarke begins the chapter by outlining the theoretical background to SCP, particularly the idea that crime is the product of a person-situation interaction. He argues that no crime can occur without opportunity, and therefore opportunity reduction is the central crime prevention strategy. Perhaps the most distinctive feature of SCP - setting it apart from CPTED for example - is its problem-solving, offence-specific approach to prevention. For Clarke, prevention can only occur after the crime problem has been specified in precise terms and the dynamics surrounding the offence fully interrogated and understood, a feature the approach shares with POP. SCP is about tailor made solutions to specific problems. While Clarke suggests a range of situational technique 
in his SCP table, these are not to be taken off-the-shelf but rather applied and adapted as the context demands. He points out that the alternative to SCP - changing offenders' criminal dispositions - can be very difficult to achieve, and in any case, significant changes in behaviour can be effected without the need to do so. Clarke reviews the empirical evidence for the success of $\mathrm{SCP}$, arguing that no other form of intervention can claim the levels of crime reduction achieved by SCP. Finally, Clarke raises and responds to the criticisms typically made of SCP, especially that it simply displaces rather than prevents crime. Not only does the empirical evidence show that displacement is far from inevitable, diffusion of benefits - reductions in crime nontargeted areas - is as just as likely to occur.

Chapter 14 is Designing Products Against Crime by Paul Ekblom. The basic logic of this approach is that some products are unintentionally criminogenic, either because they become targets for crime (e.g., mobile phones) or they otherwise assist the commission of crime (e.g., the Internet). The conceptual roots for designing products against crime can be found in CPTED, RAA, RCP and SCP. Ekblom sets the scene for this chapter by starting with some examples of well-designed products (from the perspective of crime prevention). From here he traces the long history of designing products against crime, citing examples such as the development of milled edges on silver coins in the $16^{\text {th }}$ century to prevent clipping, and eventually the replacement of silver with base metals in the $20^{\text {th }}$ century to make the coins intrinsically worthless. But Ekblom points out that it is the future orientation of design against crime that makes it significant - ideally it is about anticipating in the design phase how new products might be misused and addressing the possible criminogenic features at that 
stage. One example Ekblom gives is the increasing reach of the Internet of Things the network of objects such as household products and control systems that are connected to the Internet - which would seem to offer many possible criminal opportunities. Ekblom examines which products feature in crime, and the role product design can play in preventing crime. Finally, he examines the challenges faced in designing products against crime, such as the trade off between style, performance, price and crime prevention qualities; dealing with offender adaptation; and motivating designers to become interested in the issue.

We end this section and the book with chapter 15, Broken Windows, by Michael Wagers, William Sousa and George Kelling. We have left broken windows to last because there are some aspects to the approach - at least as it has been famously operationalised in New York City - that arguably stretch the concept of ECCA. Theoretically the broken windows approach draws on CPTED and social psychology, and to that extent makes a 'traditional' ECCA argument that crime prevention can involve environmental design to reduce incivility. But in practice the broken windows approach has also involved the arrest of minor offenders (such as turnstile jumpers and pan-handlers) to prevent escalation to serious offending, a strategy that seems to owe more the concept of offender versatility and self-selection. The chapter begins by setting out the rationale for the broken windows approach. It then traces the history of the implementation of the approach in New York, and presents an evaluation of its success. The chapter proceeds by working through the eight core principles of broken windows: that disorder and fear of crime are closely linked; that police negotiate rules of the street; that rules differ between neighbourhoods; that untended disorder leads to 
a breakdown of control; that where this occurs criminal invasion may also occur; that police should reinforce informal community control mechanisms; that problems arise from the aggregation of disorder; and that different neighbourhoods have different capacities to manage disorder. The authors deal directly with the charge that broken windows amounts to zero-tolerance policing, arguing that it is the exercise of police discretion in broken windows that makes the difference. Nevertheless, this chapter brings us back to the perhaps sobering recognition that arresting offenders remains part of the arsenal in the fight against crime.

\section{References}

Beirne, P. (1993). Inventing Criminology. Albany, NY: SUNY Press.

Braithwaite, A., \& Johnson, S. D. (2012). Space-time modeling of insurgency and counterinsurgency in Iraq. Journal of Quantitative Criminology, 28(1): 31-48.

Brayley, H., Cockbain, E., \& Laycock, G. (2011). The value of crime scripting: Deconstructing internal child sex trafficking. Policing, 5(2): 132-143.

Brantingham, P.J. and Brantingham, P.L. (eds.) (1981). Environmental Criminology. Beverly Hills, CA: Sage Publications.

Brantingham, P.L. and Brantingham, P.J., (1981). Notes on the geometry of crime. In P.J. Brantingham and P.L. Brantingham (eds.) Environmental Criminology, Beverly Hills, CA: Sage Publications.

Brantingham, P.J., and Brantingham, P.L. (1984). Patterns in Crime. New York: MacMillan

Brantingham, P.J., and Brantingham, P.L. (1991). Introduction: The dimensions of crime. In P. Brantingham and P. Brantingham (eds), Environmental Criminology ( $2^{\text {nd }}$ ed.). Prospect Heights, IL: Waveland Press.

Brantingham, P.L., and Brantingham, P.J. (1993). Environment, routine and situation: Towards a patterns theory of crime. In R.V. Clarke and M. Felson, (eds.) 
(1993). Routine Activity and Rational Choice. Advances in Criminological Theory, Vol. 5. New Brunswick, NJ: Transaction Publishers.

Bullock, K., Clarke, R.V., \& Tilley, N. (eds.) (2010). Situational Crime Prevention of Organised Crimes. Cullompton, UK: Willan.

Burgess, E.W. (1928). The growth of the city. In R.E. Park, E.W. Burgess and R.D. McKenzie (eds). The City. Chicago, IL: University of Chicago Press.

Clarke, Ronald V.G. (1967). Seasonal and other environmental aspects of abscondings by approved school boys. British Journal of Criminology, 7: 195206.

Clarke, R.V. (1980). 'Situational' crime prevention: Theory and practice. British Journal of Criminology, 20: 136-147.

Clarke, R.V. (ed.) (1992). Situational Crime Prevention: Successful Case Studies. Albany, NY: Harrow and Heston.

Clarke, R.V. (ed.) (1997). Situational Crime Prevention: Successful Case Studies. $2^{\text {nd }}$ ed.). Albany, NY: Harrow and Heston

Clarke, R. (1999) Hot Products: Understanding, Anticipating and Reducing Demand for Stolen Goods, Police Research Series Papers 112, London: Home Office.

Clarke, R.V. and Cornish, Derek B. (1985). Modeling offenders' decisions: A framework for research and policy. In M. Tonry N. Morris (eds), Crime and Justice: An Annual Review of Research, Vol. 6,. Chicago: University of Chicago Press.

Clarke, R.V. and Eck, J. (2003). Become a Problem-solving Crime Analyst. London: Jill Dando Institute of Crime Science.

Clarke, R.V., and Felson, M. (eds.) (1993). Routine Activity and Rational Choice. Advances in Criminological Theory, Vol. 5. New Brunswick, NJ: Transaction Publishers.

Clarke, R.V., and R. Homel (1997). A revised classification of situational crime prevention techniques.' In S.P. Lab (ed.) Crime Prevention at the Crossroads. Cincinnati, $\mathrm{OH}$ : Anderson.

Clarke, R.V., and Newman, G.R. (2006). Outsmarting the Terrorists. Santa Barbara, CA: Praeger.

Cockbain, E. \& Wortley, R. (2015). Everyday atrocities: Does internal (domestic) sex trafficking of British children satisfy the expectations of opportunity theories of crime? Crime Science, 4:35 
Cohen, L.E., and Felson, M. (1979). Social change and crime rate trends: A routine activity approach. American Sociological Review, 44: 588-608.

Cornish, D.B. (1994). The procedural analysis of offending and its relevance for situational prevention. In R.V. Clarke (ed) Crime Prevention Studies, Vol. 3. Monsey, N.Y.: Criminal Justice Press.

Cornish, D.B. and R.V. Clarke (eds.) (1986). The Reasoning Criminal. Rational Choice Perspectives on Offending. New York, NY: Springer-Verlag.

Cornish, D.B., and Clarke, R.V. (2003). Opportunities, precipitators and criminal dispositions: A reply to Wortley's critique of situational crime prevention. In M.J. Smith and D.B. Cornish (Eds.), Theory for Practice in Situational Crime prevention. Crime Prevention Studies, Volume 16. Monsey, NJ: Criminal Justice Press.

Ekblom, P. (1979). A crime free car? Home Office Research Bulletin 7. London: Home Office.

Emig, M., Heck, R., and Kravitz, M. (1980). Crime Analysis: A Selected Bibliography. Washington, DC: US National Criminal Justice Reference Service.

Farrell, G. and Pease, K. (1993). Once bitten, twice bitten. Repeat victimisation and its implications for crime prevention. Crime Prevention Unit Paper 46. London: Home Office.

Felson, M. (1994). Crime and Everyday Life: Insights and Implications for Society. Thousand Oaks, CA: Pine Forge.

Felson, M. (1998). Crime and Everyday Life (2 ${ }^{\text {nd }}$ ed.). Thousand Oaks, CA: Pine Forge.

Freilich, J.D. and Newman, G.R. (eds) (2009). Reducing Terrorism through Situational Crime Prevention, Crime Prevention Studies Vol 25, Monsey, NY: Criminal justice Press

Goldstein, H. (1979). Improving policing. A problem-oriented approach. Crime and Delinquency, 25, 236-258.

Goldstein, H. (1990). Problem-oriented Policing. New York: McGraw Hill.

Holt, T. J., \& Bossler, A. M. (2016). Cybercrime in Progress: Theory and prevention of Technology-Enabled Offenses. Abington: Routledge. 
Jacobs, J. (1961). The Death and Life of Great American Cities. New York: Random House.

Jeffery, C.R. (1971). Crime Prevention Through Environmental Design. Beverly Hill, CA: Sage.

Jeffery, C.R. (1977). Crime Prevention Through Environmental Design ( $2^{\text {nd }}$ ed.). Beverly Hill, CA: Sage.

Jones, E.E. (1979). The rocky road from acts to dispositions. American Psychologist 34: $107-117$

Lemieux, A. M. (ed.) (2014). Situational Prevention of Poaching. Abington; Routledge.

Marchione, E., \& Johnson, S. D. (2013). Spatial, temporal and spatio-temporal patterns of maritime piracy. Journal of Research in Crime and Delinquency, 50(4): 504-524.

Mayhew, P., Clarke, R. V., Sturman, A., and Hough, J. M. (1976)._Crime as opportunity. Home Office Research Study. No. 34. London: Home Office.

McNally, M.M. and Newman, G.R. (eds) (2007). Perspectives on identity theft. Crime Prevention Studies. Vol. 23. Monsey, N.Y.: Criminal Justice Press.

Mischel, W. (1968). Personality and Assessment. New York, NY: Wiley.

Moreto, W.D., \& Clarke, R.V. (2013). Script analysis of the transnational illegal market in endangered species: Dream and reality. In B. Leclerc, \& R. Wortley (eds). Cognition and Crime: Offender Decision-Making and Script Analyses. London: Routledge.

Newman, G.R., and Clarke, R.V. (2003). Superhighway Robbery: Preventing Ecommerce Crime. Cullompton, UK: Willan Publishing.

Newman, O. (1972). Defensible Space: Crime Prevention Through Urban Design. New York: MacMillan.

Park, R.E. (1952). Human Communities, Glencoe, IL: The Free Press.

Rengert, G., \& Wasilchick, J. (2000). Suburban burglary: A Tale of Two Suburbs $\left(2^{\text {nd }}\right.$ ed.). Springfield, IL: Charles C. Thomas.

Ross, L. (1977). The intuitive psychologist and his shortcomings: Distortions in the attribution process. In L. Berkowitz (ed.), Advances in Experimental Psychology (Vol.10), New York, Academic Press. 
Rossmo, D. K. (2000). Geographic Profiling. Boca Raton, FL: CRC Press.

Savona, E.U., Giommoni, L., \& Mancus, M. (2013). Human trafficking for sexual exploitation in Italy. In B. Leclerc, \& R. Wortley (eds). Cognition and Crime: Offender Decision-Making and Script Analyses. London: Routledge.

Shaw, C.R., and McKay, H.D. (1969). Juvenile Delinquency and Urban Areas. Chicago, Il: University of Chicago Press.

Sherman, L., Gartin, P., and Bueger, M. (1989). Hot spots of predatory crime: Routine activities and the criminology of place. Criminology, 27: 27-55.

Skinner, B.F. (1953). Science and Human Behavior. New York: MacMillan.

Townsley, M., Johnson, S. D., and Ratcliffe, J. H. (2008). Space-time dynamics of insurgent activity in Iraq. Security Journal, 21(3): 139-146.

Townsley, M., Leclerc, B., and Tatham, P. (2015). How super controllers prevent crimes: Learning from modern maritime piracy. British Journal of Criminology, First published Online 15 July 2015.

Townsley, M. and Oliveira, A. (2015). Space-time dynamics of maritime piracy. Security Journal, 28:217-229,

Wilson, J.Q., and Kelling, G.L. (1982). Broken windows: The police and neighborhood safety. The Atlantic Monthly (March): 29-38.

Wortley, R. (2001). A classification of techniques for controlling situational precipitators of crime. Security Journal, 14(4): 63-82.

Wortley, R. (2002). Situational Prison Control: Crime Prevention in Correctional Institutions. Cambridge: Cambridge University Press.

Wortley, R. \& Smallbone, S. (2006). Child Pornography on the Internet. ProblemOriented Guides for Police Series. Washington DC: U.S. Department of Justice

Wortley, R. \& Smallbone, S. (2012). Internet Child Pornography: Causes, Investigation and Prevention. Santa Barbara, CA: Praeger. 
Table 1.1 Chronology of seminal environmental criminological approaches

\begin{tabular}{|c|c|c|c|}
\hline Year & Concept & $\begin{array}{c}\text { Primarily } \\
\text { Associated with }\end{array}$ & Seminal Publication \\
\hline 1971 & $\begin{array}{l}\text { Crime Prevention through } \\
\text { Environmental Design }\end{array}$ & C. Ray Jeffrey & $\begin{array}{l}\text { Crime Prevention Through } \\
\text { Environmental Design } \\
\text { (Jeffery, 1971). }\end{array}$ \\
\hline 1972 & Defensible Space & Oscar Newman & $\begin{array}{l}\text { Defensible Space: Crime } \\
\text { Prevention Through Urban } \\
\text { Design (Newman, 1972). }\end{array}$ \\
\hline 1976 & $\begin{array}{l}\text { Situational Crime } \\
\text { Prevention }\end{array}$ & Ron Clarke & $\begin{array}{l}\text { Crime as Opportunity } \\
\text { (Mayhew, Clarke, Sturman \& } \\
\text { Hough, 1976) }\end{array}$ \\
\hline 1979 & $\begin{array}{l}\text { Routine Activities } \\
\text { Approach }\end{array}$ & Marcus Felson & $\begin{array}{l}\text { Social change and crime rate } \\
\text { trends: A routine activity } \\
\text { approach (Cohen and Felson, } \\
\text { 1979). }\end{array}$ \\
\hline 1979 & $\begin{array}{l}\text { Problem Oriented } \\
\text { Policing }\end{array}$ & $\begin{array}{l}\text { Herman } \\
\text { Goldstein }\end{array}$ & $\begin{array}{l}\text { Problem Oriented Policing } \\
\text { (Goldstein, 1979). }\end{array}$ \\
\hline 1981 & $\begin{array}{l}\text { Geometry of Crime / } \\
\text { Crime Pattern Theory }\end{array}$ & $\begin{array}{l}\text { Pat \& Paul } \\
\text { Brantingham }\end{array}$ & $\begin{array}{l}\text { Environmental Criminology } \\
\text { (Brantingham and } \\
\text { Brantingham, 1981) }\end{array}$ \\
\hline 1982 & Broken Windows & $\begin{array}{l}\text { James Q. } \\
\text { Wilson \& }\end{array}$ & $\begin{array}{l}\text { Broken Windows: The Police } \\
\text { and Neighborhood Safety, }\end{array}$ \\
\hline
\end{tabular}




\begin{tabular}{|l|l|l|l|}
\hline & & George Kelling & (Wilson and Kelling, 1982) \\
\hline 1985 & Rational Choice & Derek Cornish & Modeling Offenders' \\
& Perspective & \& Ron Clarke & $\begin{array}{l}\text { Decisions: A Framework for } \\
\text { Research and Policy. (Clarke } \\
\text { and Cornish, 1985) }\end{array}$ \\
& & & \\
\hline
\end{tabular}

